\title{
ASAP CAIR SEBAGAI BAHAN PENGAWET PANGAN
}

\author{
Sugihartono *)
}

\begin{abstract}
There are some shocking fact that found in food, such as wet noodie, meat balls, tofu, chicken meat, fish and cracker products contain a very dangerous ingredient which is formaldehyde and borax. To replace this dangerous ingredient we can use wood vinegar. Phenol and organic acid is an ingredient in wood vinegar that can acts as anti bacterial or bacteriostatic. The combination of these can work effectively against microbe growth. Phenol compound also have a great antioxidant activities. It's much practical and hygiene when using wood vinegar as a food preservative., in smoke process we can control taste, color and odor of the product, much quickly than the traditional ways. This preservative also decrease carcinogenic contain in preserving food. Its can avoid tar compound deposit and polysiclic aromatic hydrocarbon compound can be decrease until two order.
\end{abstract}

Keywords : wood vinegar, preservative, chemical compound

\section{PENDAHULUAN}

7 elah beredar di pasar beberapa jenis bahan pangan seperti; mie basah, bakso, tahu, ayam, ikan, dan kerupuk serta pangan jajanan lainnya diketahui mengandung bahan pengawet yang dilarang penggunaannya sebagai bahan tambahan pangan (BTP); bahan tersebut adalah formalin dan atau boraks (BPOM, 2006 dan BBPOM, 2006).

Terdapat beberapa jenis bahan pengawet yang dilarang untuk BTP karena apabila terhirup, mengenai kulit dan tertelan berbahaya bagi kesehatan, keselamatan dan keamanan. Akibat yang ditimbulkan dapat bermacam-macam tergantung dari jenisnya seperti; luka bakar pada kulit, iritasi pada saluran pernafasan, reaksi alergi, mual, nyeri hebat pada perut bagian atas, pendarahan gastro-enteritis disertai mutah darah, diare, lemah, mengantuk, demam, sakit kepala, kanker dan bahkan dalam dosis tinggi dapat menyebabkan kematian.

Sosialisasi secara berkala dan berkesinambungan tentang pelarangan dan bahaya penggunaan bahan pengawet yang dilarang sebagai bahan tambahan pangan (BTP) serta penerapan sanksi yang tegas pada produsen yang melanggarnya perlu dilakukan untuk melindungi masyarakat dari gangguan kesehatan, keselamatan dan keamanan pangan.

Bersamaan dengan itu perlu juga diperkenalkan dan dianjurkan penggunaan BTP yang dijinkan penggunaannya yang dapat melindungi produk dari kerusakan dan aman bagi manusia. Bahan pengawet alami yang memiliki peluang untuk dijadikan sebagai BTP adalah asap cair.

\section{Penggunaan Asap Sebagai Bahan Pengawet Pangan}

Penggunaan asap untuk pengawetan bahan pangan telah dikenal sejak lama dan dilakukan oleh nenek moyang kita. Mereka menempatkan biji-bijian terutama jagung atau padi diatas tungku pemasakan yang berbahan bakar kayu, dengan tujuan agar bahan tidak diserang serangga atau bubuk, sehingga bahan awet dan dapat dipergunakan sebagai bahan cadangan pangan.

Penggunaan asap juga telah digunakan oleh sebagian penduduk pedesaan di Kalimantan Selatan untuk pengawetan daging rusa hasil buruan, dengan tujuan agar daging tidak berjamur 
dan berbau. Biasanya daging hasil buruan terlebih dahulu dipotong-potong, kemudian digarami untuk selanjutnya dikeringkan diatas perapian yang berbahan bakar kayu. Daging yang telah diperlakukan demikian dapat tahan simpan berbulan-bulan. Disamping itu asap juga telah digunakan untuk pengawetan ikan.

Asap dari pembakaran bahan berligno sellulosa memiliki komposisi kimia fenol, formaldehida, uap air, asam formiat, asam asetat, keton, alkohol, dan karbon dioksida serta senyawa karbonil lainnya. Senyawa fenol dan formaldehida masing-masing bersifat bakterisida, dan kombinasinya bersifat fungisida (Anonim, 2003). Senyawa penol bersifat toksik melalui ingestion, penyerapan kulit, dan iritan kuat bagi kulit, sedangkan formaldehida juga bersifat racun, mudah diserap kulit dan iritan terhadap mata dan kulit ( Lewis, R.J., 1993).

Dari kandungan asap tersebut sehingga dapat digunakan untuk mengawetkan jagung dari serangan serangga/bubuk, dan dapat mengawetkan daging dan ikan dari kerusakan akibat mikrobia perusak dan pembusuk serta jamur.

\section{Pengertian Asap Cair}

Asap cair adalah cairan organik yang berwarna kuning sampai hitam, berbau sengak, mengandung banyak komponen kimia yang dapat dikelompokkan pada senyawa asam, fenol, dan alkohol netral ( Puslitbang Teknologi Hasil Hutan, 2004 ). Diperoleh dari limbah yang berupa uap/gas yang terjadi selama proses pembuatan arang dengan cara mengkondensasikannya dengan atau tanpa alat pendingin, biasanya menjadi satu kesatuan dalam proses pembuatan arang. Nama lain asap cair adalah cuka kayu atau wood vinegar.

Asap cair yang diperoleh langsung dari kondensasi asap hasil pembakaran bahan berlignoselulosa masih mengandung tar, char dan kotoran lainya, oleh karena itu perlu dimurnikan terlebih dahulu sebelum digunakan sebagai pengawet pangan.

\section{Kandungan Asap Cair}

Tranggono, dkk (1997) menyatakan bahwa sifat-sifat asap cair beragam tergantung pada bahan dasar kayu yang digunakan. Sugihartono (2006) juga melaporkan bahwa senyawa asap cair yang dihasilkan dari tiga jenis dan diameter kayu Mangrove tidak sama, baik konsentrasi maupun macam senyawa fungsionalnya.

Kandungan asap cair sesuai dengan kandungan gas dan atau senyawa yang mudah menguap pada proses pembuatan arang yang dapat dikondensasikan. Senyawa kimia asap asal pembakaran bahan berligno-selulosa adalah; fenol, formaldehida, uap air, asam formiat, asam asetat, keton, alkohol, karbon dioksida dan senyawa karbonil lainnya termasuk polisiklik aromatik hidrokarbon ( $\mathrm{PAH}$ ). Senyawa PAH terdiri dari gabungan cincin benzen yang secara teoritis terdapat sampai 100 senyawa, salah satu diantaranya adalah benzopiren yang bersifat sangat karsinogenik (Maga, 1987 dalam Tranggono dkk., 1997 ). Asap cair dengan kadar benzopiren rendah dapat diproduksi dengan peralatan proses yang terdiri dari reaktor yang dilengkapi pemanas listrik, pemisah embunan, ter, pengembun asap dan penyerap dengan isian zeolit (Tranggono, dkk., 1996).

Menurut Maga, 1987 di dalam Wiyoto, 2000 bahwa pirolisis hemiselulosa akan terdekomposisi menjadi furan dan turunannya; lignin akan terdekomposisi menjadi guaiakol, 4metil guaiakol, 4-etil guaiakol, dan asetavanilon; sedangkan selulosa akan terdekompisisi menjadi char, tar, levoglukosan, 1,6 anhidro- $\beta$-glukofuranon dan material yang mudah mengalami hidrolisis

Terdapat 20 senyawa yang berada pada asap cair batok kelapa, namun demikian hanya ada tiga senyawa pokok yaitu alkohol, aldehida dan senyawa asam. Setelah ditelaah, alkohol dan aldehida dari asap cair batok kelapa tersebut ternyata mempunyai gugus kimia rantai panjang yang tidak beracun dan justru membunuh bakteri pembusuk ( Setiadji B di dalam Arviza Y dan Amin S.., 2006).

Asap cair murni mengandung lebih dari 200 komponen kimia, termasuk asam asetat, metil alkohol, aseton dan sejumlah kecil komponen kimia lainnya, serta memiliki kandungan air tinggi yaitu $80 \%$ sampai $90 \%$ (www.sumiworld.com. 2004 ). Yatagai (2004) melaporkan bahwa asap cair terdiri dari campuran 200 komponen, memiliki kadar air $80 \%$ sampai $90 \%$, kandungan bahan organik $10 \%$ sampai $20 \%$ yang terdiri dari; asam, alkohol, bahan netral, fenol, dan komponen nitrogen; serta memiliki derajad keasaman tinggi yaitu $\mathrm{pH} 23$.

Senyawa fenol dan asam organik adalah dua senyawa dalam asap cair yang memiliki sifat bakterisidal/bakteriostatik, kombinasi keduanya dapat bekerja secara efektif untuk mengontrol 
pertumbuhan mikrobia. Disamping itu fenol juga memiliki saktivitas antioksidan yang cukup besar. Dari sifat ini maka asap cair dapat dianjurkan untuk digukanakan sebagai BTP yang cukup aman untuk menggantikan BTP yang dilarang seperti formalin dan boraks.

\section{Mengapa Menggunakan Asap Cair}

Pengasapan tradisional atau pengasapan langsung sulit untuk dikontrol, karena konsentrasi konstituen asap, waktu operasional, dan suhu pengasapan tidak dapat dipertahankan sama, sehingga sukar untuk memperoleh mutu produk yang seragam pada waktu dan atau tempat yang berlainan. Terdapat beberapa alasan tentang penggunaan asap cair sebagai pengawet bahan pangan antara lain; penggunaan asap cair lebih menguntungkan karena proses pengasapan dapat dilakukan lebih cepat, kemungkian menghasilkan produk karsiogenik lebih kecil, dan warna serta cita rasa produk dapat dikendalikan (Hollenbec, 1977 dalam Hadiwiyoto, dkk ., 2000).

Disamping itu penggunaan asap cair dari bahan berligno-selulosa tertentu aman untuk pengawetan bahan pangan. Arviza Y dan Amin S ( 2006 ) melaporkan bahwa asap cair batok kelapa ala Kulonprogo telah mendapatkan sertifikat aman sebagai bahan pengawet pangan dari Kanada dan Malaysia. Deposit senyawa tar pada bahan pangan dapat dicegah, karena digunakan asap cair yang telah dimurnikan atau tarnya dipisahkan. Keuntungan lainnya adalah senyawa polisiklik aromatik hidrokarbon dapat diturunkan sebanyak dua orde dibandingkan pengasapan biasa dalam proses pengasapan produk daging ( Semko, et.al., 1972 dalam Tranggono, dkk., 1996).

Keunggulan lainnya adalah lebih praktis dan higienis, tidak perlu penggunaan panas sehingga bahaya kebakaran dan pencemaran lingkungan akibat asap dapat dihindari. Lebih higienis karena tempat pengawetan dengan asap cair dapat terpisah dari tempat proses produksi asap cair. Dengan cara ini industri pangan yang menggunakan asap cair sebagai BTP dimungkinkan untuk tidak memproduksi sendiri asap cairnya. Produsen arang dapat sekaligus memproduksi asap cair sehingga terdapat nilai tambah dari proses produksi arangnya.

\section{Cara Penggunaan Asap Cair Untuk Pengawetan Pangan}

Agar asap cair aman digunakan sebagai bahan pengawet pangan, maka perlu dilakukan pemisahan tar dan char beserta kotoran lainnya dari dalam asap cair, kemudian pilih yang kandungan PAH nya rendah terutama senyawa benzopirin. Di Jerman kadar maksimum benzopirin dalam bahan makanan yang diijinkan adalah 1 ppb (Tilgner, 1968 dalam Tranggono, 1996 ). Pemisahan tar, char dan kotoran lainnya dari dalam asap cair dapat dilakukan dengan pengendapan, penyaringan atau penyulingan/distilasi.

Selanjutnya tentukan dosis dan cara aplikasinya. Tahapan ini dapat dilakukan melalui serangkaian percobaan pengawetan untuk memperoleh hasil yang dikehendaki seperti daya awet, cita rasa, warna dan aroma. Pencelupan daging dan ikan dalam asap cair yang telah diencerkan 1 : $10(\mathrm{v} / \mathrm{v})$ selama 30 detik menghasilkan produk yang secara organoleptik paling dapat diterima konsumen (Suhardi dkk. 1996).

Cara penggunaan asap cair dapat dilakukan dengan penyemprotan, pencelupan dan perendaman dengan atau tanpa bahan tambahan lainnya seperti garam, dan bumbu serta rempah-rempah. Biasanya sebelum digunakan untuk pengasapan, asap cair diencerkan terlebih dahulu dan digunakan pada konsentrasi $1020 \%$. Setiadji B. dalam Arviza Y dan Amin S ., 2006, melaporkan bahwa asap cair asal batok kelapa dari Kulonprogo dapat digunakan untuk mengawetkan ikan bandeng dan tahu sehingga bisa tahan simpan selama 25 hari. Setengah liter asap cair cukup untuk mengawetkan 1000 ikan bandeng. Pujilestari ( 2007 ) melaporkan bahwa tahu dan bakso yang diawetkan dengan asap cair kayu galam kodisinya masih tetap baik dalam penyimpanan selama 14 hari.

\section{KESIMPULAN}

Telah ditemukan beberapa jenis bahan pangan seperti mie basah, bakso, tahu, ayam, ikan, dan kerupuk mengandung BTM yang dilarang penggunaannya yaitu formalin dan atau boraks.

Penggunaan asap untuk pengawetan bahan pangan telah dilakukan sejak lama, namun mutu produk sulit untuk dikontrol. Senyawa fenol dan asam organik adalah dua senyawa dalam asap cair yang memiliki sifat bakterisidal / bakteriostatik, kombinasi keduanya dapat bekerja secara efektif untuk mengontrol pertumbuhan mikrobia; senyawa fenol juga memiliki saktivitas antioksidan yang cukup besar. 
Penggunaan asap cair lebih menguntungkan karena lebih praktis dan higienis, proses lebih cepat, warna, dan cita rasa produk dapat dikendalikan, serta kemungkian senyawa karsinogenik lebih kecil; deposit senyawa tar dapat dicegah, dan senyawa PAH dapat diturunkan sebanyak dua orde.

Asap cair batok kelapa ala Kulonprogo telah mendapatkan sertifikat aman sebagai bahan pengawet pangan dari Kanada dan Malaysia. Asap cair dapat digukanakan sebagai BTP yang cukup aman.

\section{Daftar Pustaka}

Anonim , BPOM ( Badan Pengawas Obat dan Makanan ), RI. 2006, Menghindari Pangan Yang Mengandung Boraks, Brosur.

BBPOM (Balai Besar Pengawas Obat dan Makanan) Banjarmasin, 2006. Mari Kita Pilih Pangan Bebas Formalin, Bosur.

Kementrian Negara Riset dan teknologi, Deputi Pendayagunaan dan Pemasyarakatan Iptek, Seri TTG Pengolahan Pangan, 2003. Daging Asap (Daging Sale) Cara Pengasapan Cair. Jakarta.

Arviza Y dan Amin S ( 2006 ) Mukjizat asap dari Kulonprogo, Tempo edisi 22 Januari 2006 halaman $56-57$.

Lewis, R.J., 1993. Hawley's Condensed Chemical Dictionary, Van Nostrand Reinhold Company, New York.

Puslitbangtek Hasil Hutan, Balitang Kehutanan, Departemen Kehutanan, 2004, Cuka Kayu ( wood Vinegar) dari Limbah Asap Industri Arang, Bogor.

Pujilestari T., 2007. Pengaruh Cara Pemisahan Cuka Kayu dari Asap Cair Kayu Galam Untuk Keperluan Industri Pengolahan Pangan, Laporan Penelitian Balai Riset dan Standardisasi industri, Banjarbaru.

Sugihartono, 2006. Komposisi dan Analisis Kegunaan Cuka Kayu Dari Tiga Jenis dan Diameter Kayu Mangrove, Tesis S-2, Program Studi Pengelolaan Sumberdaya Alam dan lingkungan, Program Pasca Sarjana, Universitas Lambung Mangkuarat, Banjarbaru.

Suhardi, Tranggono, Darmadji P., Setiadji B., Supranto dan Sudarmanto, 1996. Pengaruh Asap Cair Terhadap Stabilitas Daging dan Ikan Asap, Makalah disampaikan pada Seminar Nasional Pangan dan Gizi dan Konggres PAPTI di Yogyakarta, 10 -11 Juli 1996.

Sumiworld, Wood Vinegar, www.sumiworld.com. Dikunjungi September 2004

Tranggono, Suhardi, Setiadji, B., Darmadji, p., Supranto, dan Sudarmanto, 1996. Identifikasi Asap Cair Dari berbagai Jenis Kayu dan Tempurung Kelapa, Makalah disampaikan pada Seminar Nasional Pangan dan Gizi dan Konggres PAPTI di Yogyakarta, 10 -11 Juli 1996. , Suhardi, Setiadji B., Darmadji P., Supranto, Sudarmanto, dan Armunanto, R., 1996. Adsorbsi Senyawa Komponen Asap Cair pada Zeolit. Makalah disampaikan pada Seminar Nasional Pangan dan Gizi dan Konggres PAPTI di Yogyakarta, 10 -11 Juli 1996. Suhardi dan Setiadji, B., 1997. Produksi asap cair dan penggunaannya pada pengolahan beberapa bahan makanan khas Indonesia, Laporan akhir riset unggulan terpadu III, Kantor Menteri Negara Riset dan Teknologi, P:royek Puspiptek.

Wiyoto, S H., Darmadji, P., Purwasari, S.R., 2000. Perbandingan Pengasapan Panas dan Penggunaan Asap Cair pada Pengolahan Ikan ; tinjauan kandungan Benzopiren, Fenol, dan sifat Organoleptik Ikan Asap,Agritech, Volume 20, No 1, hal 14-19.

Yatagai, M., 2004. Utilization of Charcoal and Wood Vinega rin Japan, Seminar on "Enhanching the Development on Production and Utilization of Charcoal and Wood Vinegar", Bogor, Indonesia. 